\title{
Artificial and Real Income Smoothing around Corporate Governance Reforms: Further Evidence from Egypt
}

\author{
Awad Elsayed Awad Ibrahim (Corresponding author) \\ Senior Lecturer of Accounting \\ Affiliation: Portsmouth Business School, Portsmouth, United Kingdom, PO1 3DE. \\ Email: awad.ibrahim@port.ac.uk; awad.mans@gmail.com \\ Tarek Abdelfattah \\ Senior Lecturer of Accounting \\ Affiliation: Portsmouth Business School, Portsmouth, United Kingdom, PO1 3DE. \\ Email: tarek.abdelfattah@port.ac.uk \\ Khaled Hussainey \\ Professor of Accounting \\ Affiliation: Portsmouth Business School, Portsmouth, United Kingdom, PO1 3DE. \\ Email : Khaled.Hussainey@port.ac.uk
}

\begin{abstract}
Purpose - We examine whether managers switch from artificial income smoothing using discretionary accruals to real income smoothing around corporate governance reform in Egypt.

Design/methodology/approach - Our sample comprises 61 non-financial companies listed on the Egyptian Stock Exchange for the years 2004-2011. We use discretionary accruals as a proxy for artificial income smoothing and income/loss from asset sales as a proxy for real income smoothing.

Findings - We add to the literature in three crucial respects. First, we show that corporate governance reform did not mitigate real income smoothing. Second, we show that managers did not smooth earnings using discretionary accruals during the period of corporate governance reform. Third, we show that real income smoothing and discretionary accruals are not substitutes.

Originality/value - We offer a significant contribution to accounting literature by providing new empirical evidence on the trade-off between real smoothing technique (e.g., income/loss from asset sales) and discretionary accruals around governance reform in a developing country.
\end{abstract}

Keywords: Governance Reform; Discretionary Accruals; Asset Sales; Income Smoothing; Egypt 


\section{Introduction}

This study investigates whether Egyptian managers switch from artificial income smoothing to real income smoothing around corporate governance reform. Egypt provides a unique country context to examine income smoothing behavior as it has paid attention to corporate governance (CG) early in 2000. It has experienced two waves of corporate governance reform, aiming at supporting economic reform programs and attracting direct foreign investments (Abdelfattah and Hussainey, 2019). The first wave focuses on increasing the awareness of CG and developing codes with guidelines and rules of good CG, while the second wave focuses on implementation issues. In this paper, we examine how the first Egyptian governance reform affects income smoothing practices.

Income smoothing is a common form of earnings management (EM) where managers can manipulate earnings in two directions, inflate or deflate net income so that income movement seems smoother and less fluctuated. Based on the method used, income smoothing could be classified as artificial, where techniques of accounting earnings management such as accruals manipulation could be implemented, or real, where methods of real earnings management could be applied such as sales of assets (Huang, Zhang, Dies, \& Moffitt, 2009; Yang, Tan, \& Ding, 2012; Khalil \& Simon, 2014).

There is a growing body of literature which examines income smoothing practices. Graham, Harvey, and Rajgopal (2005) find that $97 \%$ of the CEOs prefer to smooth income as this leads to a lower cost of capital, a higher credit rating, and easier earnings predictions for both analysts and investors. Managers believe that a smoother income assures customers and suppliers and other stakeholders that the business is stable. In a related study, Dichev, Graham, Harvery, and Rajgopal (2013) find that CFOs believe that stakeholders will not be able to unravel earnings management using real actions. They also highlight the case of ambivalence about smoothness, where some consider smoothness as a desirable quality of earnings, while others consider it as opportunistic behavior. In addition, they highlight that executives praise smooth earnings as consistent and reliable but decry over smoothing of earnings.

While managers believe in the benefits of income smoothing, empirical evidence shows negative consequences. For example, Poitras, Wilkins, and Kwan (2002) argue that income smoothing could impose costs and that managers are likely to sacrifice when smoothing income. Moreover, Jayaraman (2008) argues that income smoothing distorts the contemporaneous information content of earnings and cash flow. The disclosure of misleading information may inhibit the efficient allocation of resources and change the decisions of the pricing of capital (McVay, 2006).

Considerable attention has been given to examining income smoothing practices using accruals and real activities. Prior studies provide evidence of employing the two techniques to smooth income in developed and developing countries (e.g., Chaney and Lewis,1998; Atik, 2009). Abdel-Azim and Ibrahim (2014) report that managers use income/loss from asset sales to smooth income in Egypt. As long as income smoothing can be done using different methods, this could enable managers to trade-off and substitute between these methods (Cohen and Zarowin, 2010). Managers may search for an easy, quick, and convenient method to smooth income and may substitute between different methods based on the strictness of the governance regulations. Cohen, Dey, and Lys (2008) find that Accrual Earnings Management (AEM) declined significantly and Real Earnings Management (REM) increased after the Sarbanes-Oxley Act (SOX). Similarly, Ipino and Parbonetti (2017) find a case of substitution of REM for AEM in EU countries with strong enforcement after IFRS adoption. Further, Huang et al. (2009) conclude that inadequate governance mechanisms induce managers to use AEM and discard REM using derivatives. 
Despite the extensive literature on earnings management, there is little research on the use of the sale of assets as an income smoothing tool in developing countries. In addition, very few studies have investigated the trade-off between accruals and real activities earnings management and the potential impact of governance reform on this trade-off. The regulators' effort to enhance transparency and earnings quality might have the unintended consequence of increasing real earnings management activities (Ipino and Parbonetti, 2017).

We add to this literature by examining the trade-off between discretionary accruals (as an accounting income smoothing method) and income/loss from asset sales (as a real income smoothing method) around the period of initiating the governance reform in Egypt. We complement prior research and uses a technique that is effective enough to smooth income, where the sale of assets could help managers to realize the unrealised capital gains or losses. It extends two closely related research papers that examine income smoothing in Egypt. These include Khalil and Simon (2014) that examines income smoothing using discretionary accruals and Abdel-Azim and Ibrahim (2014) that examines real income smoothing by using income/loss from asset sales.

The remainder of the paper is as follows. Section 2 presents the governance reform in the Egyptian context. Section 3 reviews the literature and develops hypotheses. Section 4 discusses the method and the sample. Section 5 presents the findings. Section 6 presents additional analyses, while Section 7 concludes.

\section{Corporate Governance in the Egyptian Context}

The Egyptian Exchange (EGX) is the first stock exchange established in the Middle East and North Africa (MENA) region, and it is considered as one of the oldest stock exchanges in the world (OECD, 2019). Egypt recognised the importance of corporate governance early in 2000. It was the first Arab country assessed by the World Bank and the International Monetary Fund against the Organisation for Economic Co-operation and Development (OECD) principles of corporate governance in 2001. The assessment report highlighted the need to strengthen some areas, including training and capacity building for regulators and the private sector, practices of boards of directors, role and effectiveness of shareholders' meetings, and the professional conduct of the accounting and auditing profession (World Bank, 2001).

Since that report, Egypt started with several initiatives of corporate governance reform. A new set of listing rules has been issued in August 2002, with a transitional period one year, emphasising timely disclosure and transparency, prohibiting insider trading, encouraging good governance practices, requiring an audit committee, and imposing for the first time penalties in case of failure to disclose on time. Besides, the EGX formed a committee for investor relations and corporate governance, playing a communication and advisory role and aiming to promote transparency and the best governance practices among the most actively traded companies. The World Bank reassessed the Egyptian corporate governance practices in its report published in 2004 and acknowledged the improvement in the corporate governance area. However, the report identified some weaknesses in governance practices such as the lack of rules governing board independence and responsibilities and the slow adoption of some governance-related concepts such as audit committees. The report recommended issuing a code for corporate governance with a rule of "comply or explain" (World Bank, 2004). More governance initiatives have been implemented in Egypt since 2003, with support from international organisations such as the OECD, International Finance Corporation (IFC) and the World Bank. Egypt established the Egyptian Institute of Directors (EIoD), the first institute dealing with corporate governance in the MENA region, in 2003 to spread the awareness of good governance practices in Egypt and the MENA region (Abdelfattah, 2018). The first Egyptian corporate governance code was issued in October 2005. The code 
presented guidelines and standards of corporate governance but lacked enforcement, as it was neither mandatory nor legally binding. Moreover, it did not follow the rule of comply or explain. In 2005, the Egyptian Capital Market Authority (ECMA) created a separate department for corporate governance, and the EGX was the best performing emerging market exchange in 2004 and 2005.

A new package of Egyptian Accounting Standards (EASs), mainly based on the International Accounting Standards, was issued in late 2006 by the ministerial decree No. 243. Egyptian listed companies were required from 2007 to prepare their financial statements according to this new set of accounting standards. Another initiative was issuing the guidelines of corporate governance for stateowned companies in July 2006. Furthermore, the EIoD issued in May 2007 a manual for audit committees. ECMA issued in 2007 resolution No. 11 on the executive rules for the governance of companies operating in the field of securities and unlisted in the stock market, followed by a manual for applying such governance rules. The 2007 resolutions come in the context of interest in developing the stock market, supporting stability, and providing more excellent protection for investors' dealing (Abdelfattah, 2018). Due to the penalties introduced in the listing rules and other governance reform activities, the number of listed companies has decreased dramatically from 1151 in 2002 to only 213 in 2011 (EGX, 2012).

Egypt has witnessed significant political turmoil after the Egyptian revolution that erupted in Egypt in 2011 and left severe economic implications. According to World Bank statistics, the real Gross domestic product declined from its highest rate during the preceding 20 years, from $7.20 \%$ in 2008 to $1.80 \%$ in 2011. Later in June 2013, another revolution erupted.

The above corporate governance reform motivates us to investigate the income-smoothing practices in Egypt during the period from 2004 until 2011. Such the reform may constitute a case of coercive isomorphism, on the most active listed companies, that stems from political pressure or influence in addition to the legitimacy issue. Therefore, this study addresses the managers' decisions and preferences to smooth income throughout corporate governance reform in a developing country that is characterized by secretive culture and risk avoidance (Abdelfattah and Hussainey, 2019). The study period ended with the year 2011 to avoid the effect of the period of severe political and economic instability.

\section{Literature Review and Hypotheses Development}

Prior studies concerning the trade-off between AEM and REM provide mixed evidence. For example, while Ipino and Parbonetti (2017) document a case of substitution in EU countries following IFRS adoption in, Campa, Cao, and Donnelly (2019)find that REM, using asset sales, has declined following IFRS in the UK. They also find that firms with high accrual balances, more use of income-increasing accruals in the past, and high opening net operating asset balances, use more asset sales to meet or beat an earnings benchmark.

A number of studies also examine the impact of governance mechanisms on earnings management. Machuga and Teitel (2009) examine how board characteristics affect earnings management and find that firms without concentrated family ownership or share directors are more likely to have more significant increases in earnings quality; proxied by income smoothing measures, timely loss recognition and accruals; than firms with more family ownership or share directors. The study also shows that cultural and legal environments are essential for corporate governance reform. In a related study, Carlson and Bathala (2003) examine how ownership affects income-smoothing behavior. They find that ownership types explain income smoothing practices. Furthermore, Epps and Ismail (2009) examine the impact of board governance on earnings management. They find that firms with annually elected boards, small boards, independent nominating committees, and independent compensation committees have more negative discretionary accruals. They conclude that income-increasing and income-decreasing discretionary accruals have different associations with the applied governance practices. Yang et al. (2012) also 
examine the effect of corporate governance on income smoothing. They find that companies with more independent directors are likely to engage in income smoothing. However, they did not find an impact of other governance mechanisms such as board size, board meetings, supervisory board, and audit committee on income-smoothing practices.

There is a lack of research on income smoothing that addresses the real income smoothing and the trade-off between different methods of earnings management, especially in emerging capital markets that witness corporate governance reforms. Therefore, this study fills this gap by providing new empirical evidence of the managers' practices of accruals and real income smoothing. The literature suggests several benefits of income smoothing. These include decreasing borrowing and debt costs (Graham et al., 2005), reducing information asymmetry and cost of capital (Poitras et al., 2002), and assuring stakeholders that the business is stable. These benefits are the main incentives for income smoothing. On the other hand, the accounting flexibility provides ample room for income smoothing using discretionary accruals. Therefore, our primary hypothesis is that managers have strong incentives to smooth income and have several techniques that could ease the process of income smoothing, diversified between accruals management and real procedures. However, the question is whether corporate governance reform could affect the possibility of income smoothing using such available methods. We expect that managers in the Egyptian context could misuse accruals and sales of assets to smooth income due to the attributes of these methods that enable managers to smooth income quickly. We also expect that governance reform could affect these practices.

\section{Income smoothing using discretionary accruals}

The nature of accruals accounting provides opportunities for managers to determine the actual earnings required in a given period (Teoh, Welch, \& Wong, 1998). Moreover, Chaney and Lewis (1998) argue that discretionary accruals could remove or offset a portion of the transitory component in the reported earnings. Thus, managers can use this as a means to achieve income-smoothing objectives. Therefore, discretionary accruals could be an effective technique to smooth income for a number of reasons. First, managers have the discretion to determine the size and timing of discretionary revenues and expenses. Second, discretionary accruals include positive accruals if managers need to smooth earnings upward and negative accruals if they are going to smooth earnings downward. Third, this technique will not commit the firm to any future action and will permit managers to reduce earnings variability significantly (Beidleman, 1973), which indicates that discretionary accruals could be a useful tool for managers to smooth income.

Empirically, Tucker and Zarowin (2006) provide empirical evidence on managers' use of discretionary accruals to smooth income in the USA. The literature shows similar evidence in different contexts such as Turkey (Atik, 2009); Egypt (Khalid and Simon, 2014); Gulf Cooperation Council (GCC) countries (Shubita, 2015). Given the abundance of income smoothing incentives and the ease and effectiveness of using discretionary accruals to smooth income, this study expects that when managers have the incentives and intention to smooth income, they are likely to think of discretionary accruals, especially when the governance rules applied are weak. Therefore, we hypothesise that:

\footnotetext{
H1: There is a negative relationship between discretionary accruals and the pre-managed income change (exclusive of discretionary accruals of the current year).
} 
Selective sale of assets is one of the main REM methods that could be used to smooth income. This method depends on historical cost accounting. Herrmann et al. (2003) document that applying historical cost accounting provides ample room for manipulation. Under the historical cost principle, the assets should be recorded at cost. However, the value of assets changes due to inflation or deflation, which creates a difference between the book value of assets and their current value. This difference is accumulated, which creates large unrealised capital gains or losses. Despite the tendency to apply fair value accounting, the historical cost principle is still prevalent, at least in the developing countries. It is costly and not an easy task to update the value of all assets, including fixed assets, to their fair values annually, which means that there will be a large portion of the firms' assets to be recorded at historical cost.

Accordingly, the sale of assets could be an effective technique to smooth income for a number of reasons. First, managers can release the unrealised capital gains by the sale of assets with current values higher than their book values and thus smooth upward, or they can release the unrealised capital losses by the sale of assets with current values lower than their book values and thus smooth income downward. Second, the sale of assets will not commit the firm to any future action and will allow managers to reduce income variability significantly (Beidleman, 1973). Empirically, Bartov (1993) and Eldenburg et al. (2011) provide empirical evidence on income smoothing using asset sales in the USA, as well as Herrmann et al. (2003) in Japan and Abdel-Azim and Ibrahim (2014) in Egypt. Given that, managers in the different business environment could have enough incentives to smooth income and have the power to decide which asset to sell and when the sale of assets could be a useful tool to smooth income. Therefore, we expect the use of asset sales to smooth income, especially when governance rules are not strictly implemented. Thus, we formulate our hypothesise as follows:

\section{H2: There is a negative relationship between income/loss from asset sales and the pre-managed income change (exclusive of income/loss from asset sales of the current year).}

\section{The trade-off between accruals and real income-smoothing techniques}

The primary objectives of CG mechanisms are to safeguard the rights of related parties and the wealth of shareholders. However, some studies, such as Cohen et al. (2008), provide evidence that after the passage of SOX, the accruals-based earnings management trend has decreased significantly, and the real earnings management trend has increased significantly. Therefore, the literature began to examine why managers prefer REM methods, especially after applying effective CG mechanisms.

The research presents several attributes that make managers prefer REM methods. First, managers can manipulate earnings through real activities anytime during the year, while accruals manipulation must take place at the end of the year (Gunny, 2010). Second, following any REM method could not be deemed a violation of accounting standards or regulations, which makes the detection costs lower than those of accounting EM (McVay, 2006). Third, AEM depends on the flexibility of accounting standards, while REM extent depends on the complexity of the business and the size of the firm; therefore, the scope of REM can be broader than that of AEM. Fourth, REM attempts may be harder to detect, since these attempts depend on operating decisions, while AEM attempts depend on accounting decisions (Schipper, 1989). This means that when stricter governance mechanisms are applied, managers are more likely to use REM.

Epps and Ismail (2009) conclude that income-increasing and income-decreasing discretionary accruals have different associations with governance practices. Yang et al. (2012) also find that firms with more independent directors are likely to engage in income smoothing, while other governance mechanisms may not affect income smoothing. By considering the findings of Cohen et al. (2008) and attributes of REM, 
we expect managers to switch to REM methods after governance reform in Egypt and use sales of assets as one of the REM methods rather than discretionary accruals. We, therefore, hypothesise that:

\section{H3: Managers are likely to switch from artificial income smoothing to real income smoothing after governance reform.}

\section{Methodology \\ 4.1 Sample \& Data}

Firms listed on the Egyptian Exchange (EGX) represent the study population. Moreover, EGX annually publishes a Disclosure Book, which contains financial data of the 50 most actively traded firms. We consider those 50 firms as our initial sample during the period of our study, covering eight years from 2004 until 2011. We exclude financial institutions due to their different accounting standards and regulations. The total number of non-financial firms in the disclosure books is 61 firms. After excluding missing data, the final sample consists of 338 firm-year observations. Table 1 describes the study sample. Panel A shows the initial and final samples, while Panel B exhibits the distribution of study firms across different industries. The fixed-effect panel regression has been used to test the research hypotheses. It is argued that fixed-effect regression could reduce any probability for the endogeneity problem (Wooldridge, 2010). The Hausman test was used and confirmed the use of the fixed-effect model.

\section{Insert Table 1 here}

\subsection{Accruals Income-Smoothing Model}

To capture accruals income smoothing, we first extract discretionary accruals, then examine its correlation with the pre-managed income change. We start our primary analysis by employing the model of Kasznik (1999). For robustness checks, we use the performance-matched discretionary accrual model.

Accordingly, we extracted the discretionary accruals when running Model 1 to be used as the dependent variable of Model 2. The pre-managed income is the primary independent variable of Model 2, with an expectation of a negative correlation.

Model 1: Kasznik (1999)'s Model

$\mathrm{TA}_{\mathrm{it}} / \mathrm{A}_{\mathrm{it}-1}=\alpha_{1}\left[1 / \mathrm{A}_{\mathrm{it}-1}\right]+\alpha_{2}\left[\left(\Delta \mathrm{REV}_{\mathrm{it}}-\Delta \mathrm{REC} \mathrm{itt}_{\mathrm{it}} / \mathrm{A}_{\mathrm{it}-1}\right]+\alpha_{3}\left[\mathrm{PPE} / \mathrm{A}_{\mathrm{it}-1}\right]+\alpha_{4}\left[\Delta \mathrm{CFO}_{\mathrm{it}} / \mathrm{A}_{\mathrm{it}-1}\right]+\varepsilon\right.$

Model 2: Accruals Income-Smoothing Model

$\mathrm{DA}_{\mathrm{it}}=\beta_{0}+\beta_{1} \Delta$ Earnings $_{\mathrm{it}}+\beta_{2}$ Debt $_{\mathrm{it}}+\beta_{3} \mathrm{CR}_{\mathrm{it}}+\beta_{4} \Delta$ Sales $_{\mathrm{it}}+\beta_{5}$ Size $_{\mathrm{it}}+\beta_{6}$ ZScore $_{\mathrm{it}}+\beta_{7} \mathrm{EAS}_{\mathrm{it}}+\beta_{8}$ Dual $_{\mathrm{it}}+\beta_{9}$ Fam $_{\mathrm{it}}+\beta_{10}$ Forgn $_{\text {it }}+\beta_{11}$ Bsize $_{i t}+\beta_{12}$ Nexc $_{\text {it }}+\varepsilon$

\subsection{Real Income-Smoothing Model}

We examine real income smoothing using the sale of assets method. Income/loss from asset sales is disclosed in the disclosure books and the vast majority of firms' annual reports. The income/loss from asset sales is the dependent variable of Model 3, while the pre-managed income change is the primary independent variable, with an expectation of a negative correlation.

Model 3: Real Income-Smoothing Model

$\mathrm{I} / \mathrm{LAS}_{\mathrm{it}}=\beta_{0}+\beta_{1} \Delta$ Earnings $_{\mathrm{it}}+\beta_{2}$ Debt $_{\mathrm{it}}+\beta_{3} \mathrm{CR}_{\mathrm{it}}+\beta_{4} \Delta$ Sales $_{\mathrm{it}}+\beta_{5}$ Size $_{\mathrm{it}}+\beta_{6}$ ZScore $_{\mathrm{it}}+\beta_{7}$ EAS $_{\mathrm{it}}+\beta_{8}$ Dual $_{\mathrm{it}}+\beta_{9}$ Fam $_{\mathrm{it}}+\beta 10$ Forgn $_{\text {it }}+\beta 11$ Bsize $_{i t}+\beta 12 \mathrm{Nexc}_{\mathrm{it}}+\varepsilon$ 


\subsection{Control Variables}

Following the literature, we control for leverage (Chaney \& Lewis, 1998; Epps \& Ismail, 2009 \& Abdel-Azim \& Ibrahim, 2014), liquidity (Hillier, McColgan, \& Werema, 2005), growth (Herrmann et al., 2003; Abdel-Azim \& Ibrahim, 2014) and firm size (Epps \& Ismail, 2009).

We also follow Zang (2012) by controlling for the firm's financial health at the beginning of the year, which is considered as the cost associated with earnings management. We use the recently modified version of Altman's Z-score (Altman et al., 2017) to capture the financial health of investigated firms:

$$
\mathrm{ZSCORE}=3.25+6.56 \mathrm{X} 1+3.26 \mathrm{X} 2+6.72 \mathrm{X} 3+1.05 \mathrm{X} 4
$$

Where X1 = Working Capital/Total Assets; X2 = Retained Earnings/Total Assets; X3 = Earnings before Interest and Taxes/Total Assets; X4 = Market Value of Equity/Book Value of Total Liabilities; Z = Overall Index.

Moreover, we use a dummy variable to control for the changes of 2007 when the new EASs and enhanced corporate governance practices were enforced in Egypt. The new EASs aim to increase the quality of financial reporting and can affect income-smoothing activities. Besides, we control for corporate governance mechanisms that can strengthen board oversight and limit the opportunities for earnings management. We capture corporate governance by board size, role duality, and percentage of non-executive directors (Ebrahim \& Abdelfattah, 2015). Furthermore, we control for ownership structure as foreign ownership, and family ownership can affect the earnings management behavior, especially in emerging capital markets (Carlson and Bathala, 2003; Wang, 2006). Table 2 exhibits our variables' definitions and measurements.

\section{Insert Table 2 here}

\section{Data Analysis \& Results}

\subsection{Descriptive Statistics}

Table 3 shows descriptive statistics. First, the minimum value of discretionary accruals (DA) is -4.217; the maximum value is 2.59 , while the mean is 0.271 . This implies that the sample firms report more positive $D A$ than negative $D A$ since the mean is positive. Second, the mean value of the income/loss from asset sales $(I / L A S)$ variable is 0.002 with a minimum value of -0.002 and a maximum value of 0.231 , which indicates that the sample firms tend to report more capital gains. Third, the mean value of $\Delta$ Earnings minus the discretionary accruals is -0.093 , which indicates that the sample firms experience more negative $\Delta$ Earnings. Further, the mean value of $\Delta$ Earnings minus income/loss from asset sales is -0.003 , which asserts that more firms report negative $\Delta$ Earnings. The models include four dummy variables (EAS, Dual, Fam, and Forgn), where their minimum value is 0, and the maximum value is 1 . The average board size is 10 members, while the mean of the ratio of non-executives on the board is $82 \%$.

\section{Insert Table 3 here}

\subsection{Pearson Correlation}


Table 4 presents Pearson correlation. It shows the relationships between the accruals incomesmoothing model variables. There is a significant positive correlation between $D A$ and $\triangle$ Earnings-DA variables at the 5\% level, indicating that the managers may not use discretionary accruals to smooth income since the expected sign should be negative. The liquidity is statistically significant and positively correlated with $D A$, and firm size is statistically significant at the $5 \%$ level and negatively correlated with $D A$. The maximum correlation between independent variables of Model 2 is 0.44 , between Fam and Forgn variables, which does not represent a severe multi-collinearity problem.

The correlation between $\mathrm{I} / L A S$ and $\triangle$ Earnings-CG is statistically significant at the $1 \%$ level and negative, implying that managers may use income/loss from asset sales to smooth income in the Egyptian business environment. Further, firm size is found to be statistically significant and positively correlated with income/loss from asset sales, as expected. The Pearson correlation shows that managers may use the income/loss from asset sales to conduct real income smoothing.

\section{Insert Table 4 here}

\subsection{Multiple Regression Results}

Prior studies indicate that using OLS regression may be inconsistent due to the heteroskedacity problem and having explanatory variables that are not strictly exogenous (Outa et al., 2019). Wooldridge (2010) argues that pooled regression can be used if there is a different sample for each year while panel regression; fixed or random effect; is employed when investigating the same sample over the years. Due to the selection of our sample, we started our empirical analysis by using the Breusch and Pagan Lagrangian multiplier test to decide the regression appropriate for our study. The results were significant, suggesting the panel data regression. Then, we used the Hausman test to evaluate the random and fixed effects. The results also were significant for the two main models, suggesting using the fixed-effect model instead of random-effect.

For both the accruals and real income-smoothing samples, we conduct the following procedures. First, we test the total sample from 2004-2011. Second, we split the primary sample into two subsamples; the first is from 2004 to 2006, before the application of reform of 2007, while the second is from 2008 to 2011, after applying the reform. We excluded the year 2007, as it is the year of application. Third, we split the primary sample into two subsamples, the first with a negative pre-managed income change and the second with a positive pre-managed income change. Therefore, we run each model five times.

\subsubsection{Accruals income-smoothing using discretionary accruals}

Table 5 shows the regression results of running the accruals income-smoothing model (Model 2). First, for the total sample (2004-2011), the R-squared is 0.60, which indicates that the explanatory power of the model is $60 \%$. The results show a significant positive correlation between discretionary accruals and $\Delta$ Earnings at $1 \%\left(\beta_{1}=0.232\right)$, which indicates that the observations with a positive pre-managed income report positive discretionary accruals, and vice versa, which contradicts the income-smoothing hypothesis. These results are inconsistent with the prior findings of Chaney and Lewis (1998) and Tucker and Zarowin (2006) who provide empirical evidence on managers' use of discretionary accruals to smooth income in the USA, Atik (2009) in Turkey, Khalid and Simon (2014) in Egypt, and those of Shubita (2015) in the GCC countries. 


\section{Insert Table 5 here}

Second, we run the model for the period before 2007. The results show that the model is statistically significant and explains about $87 \%$ of the discretionary accruals variations, where $R$-squared $=87 \%$. Further, the results show a significant positive correlation between $\triangle$ Earnings and $D A$ variables at $1 \%$. This result implies that firm-year observations with a positive pre-managed income report positive discretionary accruals, and vice versa, which contradicts the accruals income-smoothing hypothesis.

Third, we rerun the model for the period after 2007. The findings indicate that the model is statistically significant and explains about $30 \%$ of the total variations in discretionary accruals. The findings also suggest that the $\triangle$ Earnings variable is statistically significant at $1 \%$ and positively correlated with $D A$, which confirms the results of both the total sample (2004-2011) and the subsample (2004-2006). These results contradict the accruals income-smoothing hypothesis.

We proceed by dividing the primary sample into two subsamples based on the sign of $\Delta$ Earnings. For the negative pre-managed $\Delta$ Earnings subsample, Table 5 shows a significant positive correlation at the $1 \%$ level between $\Delta$ Earnings and discretionary accruals. This result implies that when the negative premanaged income decreases, firms report less negative discretionary accruals, which contradicts the accruals income-smoothing hypothesis. However, the correlation is statistically insignificant between $\Delta$ Earnings and discretionary accruals for the positive $\Delta$ Earnings subsample.

In summary, we did not find any empirical evidence that managers in the Egyptian business environment use discretionary accruals to smooth income, whether before or after 2007, or when earnings changes are positive or negative. Regarding the control variables, the Debt variable is found to be statistically insignificant for all the samples and subsamples in Table 5, which indicates that leverage is not a determinant of discretionary accruals. This result contradicts our expectations and arguments of Chaney and Lewis (1988) and Epps and Ismail (2009) that firms with higher leverage ratios are more likely to report positive discretionary accruals to appear less likely to default on debt payments. The variable $C R$ is found to be statistically significant and negatively correlated with discretionary accruals for the before 2007 sample only.

The Size variable is found to be negative and statistically significant at the $1 \%$ level for all the samples except the positive subsample, as shown in Table 5. This result asserts that there is an influence of firm size on EM (Epps \& Ismail, 2009). However, the result contradicts our argument that this influence should be positive since more substantial firms are under higher pressure to meet or beat the predicted earnings and may resort to using discretionary accruals to manage earnings upward. The coefficient of the ZScore variable is found to be significant and positive for three samples, which indicates a kind of relation between the probability of going bankrupt and DA.

\subsubsection{Real income-smoothing using asset sales}

Table 6 presents the regression results of running the real income-smoothing model (Model 3). The correlation between income/loss from asset sales (I/LAS) and the pre-managed $\triangle$ Earnings is found to be negative and statistically significant at the $1 \%$ level for all samples and subsamples except for the positive $\Delta$ Earnings subsample. First, the result of the total sample (2004-2011) implies that managers in the Egyptian business environment use income/loss from asset sales to smooth income. This result is consistent with some prior studies such as Bartov (1993) in the USA, Herrmann et al. (2003) in Japan, 
and Abdel-Azim and Ibrahim (2014) in Egypt. The result also confirms that of the Pearson correlation test, as shown in Table 4. Accordingly, $\mathrm{H} 2$ is accepted.

Second, Table 6 shows a significant negative correlation between asset sales and the pre-managed income before and after the governance reform in 2007, which implies that the managers' practices of real income smoothing have not been affected. The result is similar to that of Yang et al. (2012), who found that governance reform did not reduce income smoothing in China. The result is not in line with our expectations and Cohen et al. (2008), who find that real earnings management decreased after SOX in 2002 in the USA. Accordingly, we reject H3.

\section{Insert Table 6 here}

Third, when we divide the total sample into negative $\Delta$ Earnings and positive $\Delta$ Earnings subsamples, the results show a significant negative correlation for the first but a meaningful positive relationship for the second, which reveals that managers smooth income using asset sales only when the pre-managed income change is negative.

Overall, these results provide important implications. First, the results of the total samples reveal that managers prefer real income smoothing than accruals income smoothing. This result may confirm the arguments in the literature on the advantages of REM methods over AEM methods. Cohen et al. (2008) find that firms switch to manage earnings using REM methods and explain that REM methods are harder to detect because they depend on operating decisions (Schipper, 1989). REM can be undertaken anytime during the year (Gunny, 2010). Besides, REM could not be deemed a violation of accounting standards or regulations (McVay, 2006). Therefore, researchers, accounting setters, and governance regulators should take into account the possibility of using REM methods to smooth income if stricter governance rules succeed in curing the accruals income-smoothing methods.

Moreover, the results of the subsamples before and after the application of the ECGC in 2007 imply that the Egyptian governance reform is not productive, especially in mitigating real income-smoothing practices, where we find that real income smoothing still exists even after the governance reform in 2007, which may confirm the argument of McVay (2006) that REM could not be deemed a violation of the accounting standards or regulations. Therefore, new governance rules should be set and specialized in treating EM through real techniques.

Finally, the results of the negative and positive pre-managed $\Delta$ Earnings subsamples imply that managers smooth income using asset sales and only when the earnings change is negative.

\section{Additional Analysis}

In this section, we present two additional tests. The first robustness test re-measures discretionary accruals using the model of Kothari et al. (2005). The performance-matched discretionary accruals model is dominant in prior studies. Kothari et al. (2005) conclude that performance-matched discretionary accrual measures enhance the reliability of the inferences from earnings management research. For a robustness check, we use the performance-matched discretionary accruals to triangulate our findings. We compute discretionary accruals (DA) using the following equation after controlling for the company's performance.

Kothari (2005)'s Model

$\mathrm{TA}_{\mathrm{it}} / \mathrm{A}_{\mathrm{it}-1}=\alpha_{1}\left[1 / \mathrm{A}_{\mathrm{it}-1}\right]+\alpha_{2}\left[\left(\Delta \mathrm{REV}_{\mathrm{it}}-\Delta \mathrm{REC}_{\mathrm{it}}\right) / \mathrm{A}_{\mathrm{it}-1}\right]+\alpha_{3}\left[\mathrm{PPE} / \mathrm{A}_{\mathrm{it}-1}\right]+\alpha_{4} \mathrm{ROA}_{\mathrm{it}}+\varepsilon$ 
Table 7 shows the results of using the model of Kothari et al. (2005), but for the total sample during 2004-2011. It shows that the results of the model of Kothari et al. (2005) support our main analysis findings where the association between $D A$ and $\triangle$ Earnings is found to be significant but positive, which confirms the previous results that managers do not use DA to smooth income.

The second robustness test develops Models 2 and 3 to examine the potential substitution/trade-off between discretionary accruals and income/loss from asset sales to smooth income. First, we developed Model 2 by adding the variable $\left(I / L A S_{i t}\right)$ as an independent variable, as shown in Model 4 . Then we developed Model 3 by including the variable $(D A)$ as an independent variable, as shown in Model 5.

Model 4: Accruals Income-Smoothing Model

$\mathrm{DA}_{\mathrm{it}}=\beta_{0}+\beta_{1} \mathrm{I} / \mathrm{LAS} \mathrm{S}_{\mathrm{it}}+\beta_{2} \Delta$ EarningS $_{\mathrm{it}}+\beta_{3}$ Debt $_{\mathrm{it}}+\beta_{4} \mathrm{CR}_{\mathrm{it}}+\beta_{5} \Delta$ Sales $_{\mathrm{it}}+\beta_{6}$ Size $_{\mathrm{it}}+\beta_{7}$ ZScore $_{\mathrm{it}}+\beta_{8}$ EAS $_{\mathrm{it}}+\beta_{9}$ Dual $_{\mathrm{it}}+\beta_{10}$ Fam $_{\text {it }}+\beta_{11}$ Forgn $_{\text {it }}+\beta_{12}$ Bsize $_{\text {it }}+\beta_{13}$ Nexc $_{\text {it }}+\varepsilon$

Model 5: Real Income-Smoothing Model

${\mathrm{I} / L A S_{i t}}_{i t} \beta_{0}+\beta_{1} \mathrm{DA}_{\mathrm{it}}+\beta_{2} \Delta$ Earnings $_{\mathrm{it}}+\beta_{3} \mathrm{Debt}_{\mathrm{it}}+\beta_{4} \mathrm{CR}_{\mathrm{it}}+\beta_{5} \Delta$ Sales $_{\mathrm{it}}+\beta_{6}$ Size $_{\mathrm{it}}+\beta_{7} \mathrm{ZScore}_{\mathrm{it}}+\beta_{8} \mathrm{EAS}_{\mathrm{it}}+\beta_{9} \mathrm{Dual}_{\mathrm{it}}+\beta_{10}$ Fam $_{\text {it }}+\beta_{11}$ Forgn $_{\text {it }}+\beta_{12}$ Bsize $_{\text {it }}+\beta_{13}$ Nexc $_{\text {it }}+\varepsilon$

Therefore, to provide evidence that managers use the two smoothing methods as substitutes, the correlation between their proxies should be significant and negative. For example, if the income/loss from asset sales increases, the discretionary accruals will decrease. However, if the managers use the two methods as complementary, the correlation should be positive, i.e. the income/loss from asset sales and the discretionary accruals should increase at the same time.

Table 8 shows the results of running Model 4. First, we find that the correlation between $D A$ and $\Delta$ Earnings is significant and positive for the total sample (2004-2011) and the negative subsample only. This confirms the results found earlier that managers do not use $D A$ to smooth income. Regarding the added variable $(I / L A S)$, we find that the income/loss from asset sales seems not to correlate with DA because all the results are statistically insignificant.

When running Model 5, Table 9 shows that the correlation between income/loss from asset sales and $\Delta$ Earnings is statistically significant and negative for the total sample and the negative subsample but positive for the positive subsample, which confirms the results reported early that managers may use capital gains/losses to smooth income. Regarding the added variable $(D A)$, Table 9 shows no significant correlation between the $D A$ and income/loss from asset sales variables, which indicates that no conclusion can be reached about the relationship between accruals and real income.

The empirical analysis offers the following interesting implications. First, income smoothing using asset sales is a more common earnings management practice in the Egyptian business environment than income smoothing using accruals. The advantages of real earnings management could explain this. For example, they are not considered a violation of GAAP or regulations for most cases. The decision to sell specific assets seems to be a reasonable business decision. Second, corporate governance reform is essential to restrain different earnings management practices. Still, they may not be able to control earnings management in the form of income smoothing using asset sales.

\section{Conclusion}

We examine accounting income smoothing using discretionary accruals and real income smoothing using income/loss from asset sales and determine whether managers substituted between the two techniques, before and after the first governance reform in Egypt. We use the pre-managed income change as the study's primary variable. We expect a negative correlation with both proxies of accruals and real income smoothing: discretionary accruals and income/loss from asset sales. We divided the primary sample into two subsamples, before and after the application of the ECGC in 2007, and into two other subsamples, the first includes the negative $\Delta$ Earnings observations and the second consists of the positive $\Delta$ Earnings observations. 
The results indicate that managers undertake income smoothing using real activities such as asset sales more often than using accounting income smoothing via discretionary accruals. However, we find that managers follow real income smoothing only during negative $\Delta$ Earnings years and after 2007. Further, we find no evidence on the governance influence on managers' practices of income smoothing. No confirmation on whether managers use accruals and real income-smoothing tools as substitutes was found. Our study informs other developing countries, particularly those located in the Middle East and North Africa region, on the potential importance of corporate governance reforms for financial reporting practices. We provide evidence that these reforms could influence managers' choices of income smoothing and earnings management practices and hence the quality of financial reporting.

We contribute to the accounting literature by providing empirical evidence on whether and how managers in the Egyptian business environment have switched from accounting to real income smoothing around the governance reforms. These results provide important implications. First, managers prefer to smooth income using real techniques than accruals techniques, which supports the arguments in the literature on managers' preference for real earnings management rather than accounting earnings management. Second, the Egyptian governance reforms in 2007 need to restrain the managers' use of real activities to smooth income, where we find them ineffective to curb real income-smoothing practices. Third, governance regulators and accounting setters should take into account the possibility of manipulating income using other techniques such as classification shifting.

Our findings are subject to at least two limitations. First, the study sample is relatively small, and the study period ended in 2011. However, the reason is that the focus of the study on the 50 most active companies that were targeted in the governance reform initiatives and to the unprecedented political instability after the Egyptian revolution in 2011. Second, due to the lack of data, our study did not consider other governance aspects such as audit committee characteristics. Future research can investigate the correlation between board and audit committee characteristics and accruals and real income-smoothing practices. Income smoothing is still an interesting research topic that invites more investigation. Further research is yet required to compare the costs and benefits of income smoothing. More research is still needed on the managers' trade-off between the accruals and other real income-smoothing techniques. 


\section{References}

Abdelfattah, T., (2018). The Second Wave of Corporate Governance in Egypt: Challenges Ahead. In D. Jamali, V. Bodolica and Y. Lapina (Eds.) Corporate Governance in Arab Countries: Specifics and Outlooks. Virtus Interpress, 70 - 88.

AbdelFattah, T. M. H., \& Hussainey, K. (2019). Development and impact of corporate governance in Egypt. In P. Weetman, \& I. Tsalavoutas (Eds.), Routledge Companion to Accounting in Emerging Economies (Routledge Companions in Business, Management and Accounting). Routledge.

Abdel-Azim, M. H., \& Ibrahim, A. E. A. (2014). Investigating the Impact of Historical Costing On Real Earnings Management: An Empirical Study. International Business \& Economics Research Journal (IBER), 13 (2), 387-400.

Altman, E. I., Iwanicz-Drozdowska, M., Laitinen, E. K., \& Suvas, A. (2017). Financial Distress Prediction in an International Context: a Review and Empirical Analysis of Altman's Z-Score Model. Journal of International Financial Management \& Accounting, 28(2), 131-171.

Atik, A. (2009). Detecting income-smoothing behaviors of Turkish listed companies through empirical tests using discretionary accounting changes. Critical Perspectives on Accounting, 20 (5), 591-613.

Beidleman, C. R. (1973). Income Smoothing: the Role of Management. The Accounting Review, 48 (4), 653-667.

Campa, D., Cao, T., \& Donnelly, R. (2019). Asset Disposal as a Method of Real Earnings Management: Evidence from the UK. Abacus, 55(2), 306-332.

Carlson, S. J., and Bathala, C. T. (2003). Ownership differences and firms' income smoothing behavior. Journal of Business Finance and Accounting 24 (2), 179-196.

Chaney, P.K. \& Lewis, C.M. (1998). Income smoothing and underperformance in initial public offerings. Journal of Corporate Finance, 4 (1), 1-29.

Cohen, D.A., Dey, A., \& Lys, T.Z. (2008). Real and Accrual-based Earnings Management in the Pre- and Post-Sarbanes Oxley Periods. The Accounting Review, 83 (3), 757-787.

Dichev, I, D., Graham, J. R., Harvey, C., and Rajgopal, S. (2013). Earnings Quality: Evidence from the field. Journal of Accounting and Economics 56, (2-3), 1-33.

Ebrahim, A., and Abdelfattah, T. (2015). Corporate governance and initial compliance with IFRS in emerging markets: The case of income tax accounting in Egypt. Journal of International Accounting, Auditing and Taxation, 24, 46-60.

Egyptian Capital Market Authority (CMA): http://www.fra.gov.eg/content/efsa_en/cma_pages_en/cma_role_en.htm (accessed on 9 Jan 2020).

Eldenburg, L. G., Gunny, K. A., Hee, K. W. \& Soderstrom, N. (2011). Earnings Management Using Real Activities: Evidence from Nonprofit Hospitals. The Accounting Review, 86 (5), 1605-1630.

Epps, R. W. \& Ismail, T. H. (2009). Board of directors' governance challenges and earnings management. Journal of Accounting \& Organizational Change, 5 (3), 390-416.

Graham, J.R., Harvey, C.R, \& Rajgopal, S. (2005). The Economic Implications of Corporate Financial Reporting. Journal of Accounting \& Economics, 40 (1-3), 3-73.

Gunny, K. A. (2010). The Relation between Earnings Management Using Real Activities Manipulation and Future Performance: Evidence from Meeting Earnings Benchmarks. Contemporary Accounting Research, 27 (3), 855-888.

Herrmann, D., Inoue, T., \& Thomas, W.B. (2003). The Sale of Assets to Manage Earnings in Japan. Journal of Accounting Research, 41 (1), 89-108.

Hillier, D., McColgan, P., \& Werema, S. (2005). Asset Sales, Operating Performance and Firm Strategy: An Empirical Analysis", Research Paper, $\{$ Online\}, Available at: http://papers.ssrn.com/sol3/papers.cfm?abstract id=650166

Huang, P., Zhang, Y., Deis, D. R. \& Moffitt, J. S. (2009). Does artificial income smoothing and real income smoothing contribute to firm value equivalently?" Journal of Banking \& Finance, 33 (2), 224-233.

Ipino, E., \& Parbonetti, A. (2017). Mandatory IFRS adoption: the trade-off between accrual-based and real earnings management. Accounting and Business Research, 47(1), 91-121.

Jayaraman, S. (2008). Earnings Volatility, Cash Flow Volatility, and Informed Trading", Journal of Accounting Research, 46 (4), 809-851.

Kasznik, R. (1999). On the Association between Voluntary Disclosure and Earnings Management. Journal of Accounting Research, 37 (1), 57-81.

Khalil, M. \& Simon, J. (2014). Efficient contracting, earnings smoothing and managerial accounting discretion. Journal of Applied Accounting Research, 15 (1), 100-123. 
Kothari, S. P., Leone, A. J. \& Wasley, C. E. (2005). Performance matched discretionary accrual measures. Accounting \& Economics, 39 (1), 163-197.

Machuga, S., and Teitel. K. (2009). Board of director characteristics and earnings quality surrounding implementation of a corporate governance code in Mexico. Journal of International Accounting, Auditing and Taxation 18 (1): 1-13.

McVay, S. E. (2006). Earnings Management Using Classification Shifting: An Examination of Core Earnings and Special Items. The Accounting Review, 81 (3), 501-531.

OECD (2019), Corporate Governance in MENA: Building a Framework for Competitiveness and Growth, Corporate Governance, OECD Publishing, Paris, https://doi.org/10.1787/2a6992c2-en.

Outa, E. R., Eisenberg, P., and Ozili, P. K. (2019). Bank earnings management using commission and fee income. Journal of Applied Accounting Research 7 (4), 428-444.

Poitras, G., Wilkins, T., \& Kwan, Y.S. (2002). The Timing of Asset Sales: Evidence of Earnings Management. Journal of Business Finance \& Accounting, 29 (7-8), 903-34.

Schipper, K. (1989). Commentary on Earnings Management. Accounting Horizons, 3 (4), 91-102.

Shubita, M. F. (2015). The impact of income smoothing on earnings quality in emerging markets: Evidence from GCC markets. Journal of Accounting in Emerging Economies, 5 (3), 299-324.

Teoh, S., Welch, I., \& Wong, T.J. (1998). Earnings management and the long-run market performance of initial public offerings. Journal of Finance, 53 (6), 1935-1974.

Tucker, J.F. \& Zarowin, P. (2006). Does income smoothing improve earnings informativeness? The Accounting Review, 81 (1), 251-270.

Wang, C-S., Tung, S., Chen-Chang, L., Lan-Fenm W., and Ching-Hui, L. (2009). Earnings Management using asset sales. International Journal of Accounting and Information Management 18 (3), 237-251.

Wang, D. (2006). Founding family ownership and earnings quality. Journal of accounting research, 44(3), 619-656.

Wooldridge, J. (2010). Econometric Analysis of Cross Section and Panel Data. MIT Press.

World Bank (2001). Report on The Observance of Standards and Codes (ROSC), Corporate Governance Country Assessment, Arab Republic of Egypt. Available at http://www-wds.worldbank.org/

World Bank (2004). Report on The Observance of Standards and Codes (ROSC), Corporate Governance Country Assessment, EGYPT. Available at: http://www.worldbank.org/ifa/rosc_cg_egyp2.pdf

Yang, C. Y., Tan, B. L. \& Ding, X. (2012). Corporate governance and income smoothing in China. Journal of Financial Reporting \& Accounting, 10 (2), 120-139.

Zang, A. Y. (2012). Evidence on the Trade-Off between Real Activities Manipulation and Accrual-Based Earnings Management. The Accounting Review, 87 (2), 675-703. 
Table (1) Sample selection and distribution by industry.

Panel A:

\begin{tabular}{|l|c|}
\hline Total number of firms in disclosure books over the period of study & 71 \\
\hline (-) financial firms & $(10)$ \\
\hline Number of non-financial companies & 61 \\
\hline Target firm year observations & 488 \\
\hline (-) missing data & $(150)$ \\
\hline Final sample (firm - year observations) & 338 \\
\hline
\end{tabular}

Panel B: Sample distribution by industry

\begin{tabular}{|l|c|c|}
\hline \multicolumn{1}{|c|}{ Sector } & $\begin{array}{c}\text { number of } \\
\text { observations }\end{array}$ & $\begin{array}{c}\% \text { of } \\
\text { Sample }\end{array}$ \\
\hline Real estate & 64 & 18.93 \\
\hline Basic resources & 20 & 5.92 \\
\hline Chemicals & 16 & 4.73 \\
\hline Construction and Materials & 56 & 16.58 \\
\hline Food and beverage & 60 & 17.75 \\
\hline Healthcare and Pharmaceuticals & 24 & 7.11 \\
\hline Industrial Goods, Services and Automobiles & 40 & 11.83 \\
\hline Personal and Household Products & 28 & 8.28 \\
\hline Travel and Leisure Total & 30 & 8.87 \\
\hline \multicolumn{1}{|c|}{ Tor| } & 338 & 100 \\
\hline
\end{tabular}


Table 2: Definitions \& Measurements of Variables.

\begin{tabular}{|c|c|c|}
\hline Symbol & Definition & Measurement \\
\hline \multicolumn{3}{|c|}{ Dependent Variables: } \\
\hline TA & Total Accruals & $\begin{array}{l}\text { TA variable equals the difference between earnings before } \\
\text { extraordinary items and cash flow from operating activities. }\end{array}$ \\
\hline DA & $\begin{array}{l}\text { Discretionary } \\
\text { Accruals }\end{array}$ & $\begin{array}{l}\text { DA variable equals the residuals resulted from running the model } \\
\text { (1), the model of Kasznik (1999). }\end{array}$ \\
\hline I/LAS & $\begin{array}{l}\text { Income/loss from } \\
\text { asset sales }\end{array}$ & $\begin{array}{l}\text { I/LAS equal the income/loss from asset sales per share deflated by } \\
\text { the share price (Bartov, 1993; Black et al. 1998). }\end{array}$ \\
\hline \multicolumn{3}{|c|}{ Independent Variables: } \\
\hline$\triangle \mathrm{REV}$ & Revenues Change & $\begin{array}{l}\triangle \mathrm{REV} \text { equals the change of net sales from the prior year to the } \\
\text { current year. }\end{array}$ \\
\hline$\overline{\Delta \mathrm{REC}}$ & $\begin{array}{l}\text { Account Receivables } \\
\text { Change }\end{array}$ & $\begin{array}{l}\triangle \mathrm{REC} \text { equals the change of net account receivables from the prior } \\
\text { year to the current year. }\end{array}$ \\
\hline PPE & $\begin{array}{l}\text { Property, Planet, and } \\
\text { Equipment }\end{array}$ & $\begin{array}{l}\text { PPE equals the gross fixed assets of the current year before } \\
\text { accumulated depreciation. }\end{array}$ \\
\hline$\triangle \mathrm{CFO}$ & $\begin{array}{l}\text { The change of cash } \\
\text { flow from operating } \\
\text { activities }\end{array}$ & $\begin{array}{l}\Delta \mathrm{CFO} \text { equals the change of cash flow from operating activities from } \\
\text { the prior year to the current year. }\end{array}$ \\
\hline$\Delta$ Earnings & Earnings Change & $\begin{array}{l}\Delta \text { Earnings is the pre-managed income change that equals the current } \\
\text { year net income before discretionary accruals or income/loss from } \\
\text { asset sales minus the prior year net income deflated by the total } \\
\text { assets of prior year (Leuz, Nanda, \& Wysocki, 2003; Tucker \& } \\
\text { Zarowin, 2006). }\end{array}$ \\
\hline \multicolumn{3}{|c|}{ Control Variables: } \\
\hline Debt & Debt Ratio & $\begin{array}{l}\text { Debt is the total of long-term debts divided by total shareholders' } \\
\text { equity (Bartov, 1993; Poitras et al. 2002). }\end{array}$ \\
\hline CR & Current Ratio & $\mathrm{CR}$ is the ratio of current assets to current liabilities. \\
\hline$\Delta$ Sales & Sales Change & $\begin{array}{l}\Delta \text { Sales is the ratio of current year net sales minus prior year net sales } \\
\text { divide by the prior year net sales. }\end{array}$ \\
\hline Size & Firm Size & Size is the natural logarithm of total assets of the current year. \\
\hline Bsize & Board Size & Total number of board members \\
\hline Dual & Rule duality & One if the CEO and Chairman are the same person and zero \\
\hline Nexc & Non-executives & Percentage of non-executive members on the board \\
\hline Zscore & Firm financial health & Modified version of Altman's ZScore (2017). \\
\hline EAS & EAS \& CG Changes & One for years started from 2007 and zero otherwise \\
\hline Fam & Family led firms & 1 if there is family members on the board and zero otherwise. \\
\hline Forgn & Foreign members & 1 if there is foreign members on the board and zero otherwise. \\
\hline
\end{tabular}


Table 3

Descriptive Statistics

\begin{tabular}{llllll}
\hline Variable & Obs & Mean & Std.Dev. & Min & Max \\
\hline DA & 338 & 0.271 & 0.485 & -4.217 & 2.59 \\
I/LAS & 338 & 0.002 & 0.016 & -0.002 & .231 \\
$\Delta$ Earnings(DA) & 338 & -0.093 & 1.183 & -20.112 & 2.185 \\
$\Delta$ Earnings (I/LAS) & 338 & -0.003 & 0.031 & -0.415 & .214 \\
Debt & 338 & 0.343 & 0.795 & -1.009 & 7.264 \\
CR & 338 & 2.142 & 2.022 & 0.073 & 17.95 \\
Sales & 338 & 0.769 & 4.57 & -0.926 & 48.362 \\
Size & 338 & 14.077 & 1.638 & 9.845 & 18.369 \\
ZScore & 338 & 7.800 & 4.643 & -18.434 & 30.154 \\
EAS & 338 & 0.66 & 0.474 & 0.0 & 1.00 \\
Dual & 338 & 0.713 & 0.453 & 0.0 & 1.00 \\
Fam & 338 & 0.352 & 0.478 & 0.0 & 1.00 \\
Forgn & 338 & 0.29 & 0.454 & 0.0 & 1.00 \\
Bsize & 9.743 & 2.854 & 0.4 & 0.933 \\
Nexc & 0.822 & 0.109 & 0.4 & \\
\hline
\end{tabular}


Table (4): Correlation Matrix

\begin{tabular}{|c|c|c|c|c|c|c|c|c|c|c|c|c|c|c|c|}
\hline Variables & (1) & (2) & (3) & (4) & (5) & (6) & (7) & (8) & (9) & (10) & (11) & (12) & (13) & (14) & (15) \\
\hline (1) DA & 1.00 & & & & & & & & & & & & & & \\
\hline (2) $1 / \mathrm{LAS}$ & -0.03 & 1.00 & & & & & & & & & & & & & \\
\hline (3) $\Delta$ Earnings-DA & $0.52 *$ & 0.05 & 1.00 & & & & & & & & & & & & \\
\hline (4) $\Delta$ Earnings-CG & 0.02 & $-0.28 *$ & 0.01 & 1.00 & & & & & & & & & & & \\
\hline (5) Debt & -0.08 & -0.03 & 0.03 & -0.00 & 1.00 & & & & & & & & & & \\
\hline (6) $\mathrm{CR}$ & $0.18^{*}$ & -0.06 & -0.01 & 0.01 & -0.08 & 1.00 & & & & & & & & & \\
\hline (7) $\Delta$ Sales & $0.12^{*}$ & -0.02 & 0.02 & 0.04 & -0.01 & 0.01 & 1.00 & & & & & & & & \\
\hline (8) Size & $-0.38 *$ & $0.12 *$ & 0.10 & -0.10 & 0.11 & $-0.16^{*}$ & -0.10 & 1.00 & & & & & & & \\
\hline (9) ZScore & 0.04 & 0.00 & 0.01 & 0.01 & -0.04 & $0.19 *$ & 0.00 & -0.05 & 1.00 & & & & & & \\
\hline (10) EAS & 0.04 & 0.03 & 0.05 & $-0.11 *$ & -0.02 & $0.21 *$ & 0.07 & 0.08 & -0.03 & 1.00 & & & & & \\
\hline (11) Dual & -0.04 & 0.07 & -0.04 & 0.00 & 0.05 & $-0.12 *$ & $-0.17 *$ & -0.08 & -0.10 & $-0.11 *$ & 1.00 & & & & \\
\hline (12) Fam & -0.06 & -0.05 & 0.06 & -0.03 & 0.07 & $-0.18^{*}$ & -0.03 & $0.36^{*}$ & 0.05 & $0.12 *$ & $-0.30 *$ & 1.00 & & & \\
\hline (13) Forgn & -0.03 & -0.03 & -0.06 & -0.03 & -0.04 & $-0.16^{*}$ & -0.02 & $0.25^{*}$ & 0.07 & -0.04 & $-0.20 *$ & $0.44 *$ & 1.00 & & \\
\hline (14) Bsize & $-0.13 *$ & 0.03 & -0.06 & -0.05 & -0.04 & 0.08 & -0.10 & $0.18 *$ & 0.05 & -0.06 & 0.03 & -0.05 & $0.14 *$ & 1.00 & \\
\hline (15) Nexc & 0.01 & $-0.12 *$ & -0.03 & 0.03 & -0.03 & $0.16^{*}$ & 0.00 & $-0.20 *$ & 0.08 & 0.02 & -0.04 & $-0.17 *$ & 0.06 & $0.38^{*}$ & 1.00 \\
\hline
\end{tabular}

\footnotetext{
* shows significance at the 0.05 level
} 
Table (5): The Results of Artificial Income Smoothing Model

\begin{tabular}{|c|c|c|c|c|c|}
\hline & (1) & (2) & (3) & (2) & (3) \\
\hline VARIABLES & Total Sample & Before 2007 & After 2007 & Negative & Positive \\
\hline \multirow[t]{2}{*}{$\Delta$ Earnings } & $0.232 * * *$ & $0.234 * * *$ & $0.181 * * *$ & $0.237 * * *$ & 0.203 \\
\hline & $(0.0125)$ & $(0.0113)$ & $(0.0296)$ & $(0.0138)$ & $(0.143)$ \\
\hline \multirow[t]{2}{*}{ Debt } & 0.00603 & 0.0544 & 0.0111 & 0.0116 & 0.0113 \\
\hline & $(0.0226)$ & $(0.134)$ & $(0.0230)$ & $(0.0346)$ & $(0.0443)$ \\
\hline \multirow[t]{2}{*}{ CR } & 0.00285 & $-0.223 * * *$ & 0.00506 & 0.00805 & 0.00700 \\
\hline & $(0.0107)$ & $(0.0685)$ & $(0.0104)$ & $(0.0198)$ & $(0.0173)$ \\
\hline \multirow[t]{2}{*}{ Sales } & 0.00209 & -0.0186 & 0.00439 & 0.00440 & -0.00490 \\
\hline & $(0.00412)$ & $(0.0140)$ & $(0.00359)$ & $(0.00546)$ & $(0.0107)$ \\
\hline \multirow[t]{2}{*}{ Size } & $-0.115^{* * *}$ & $-0.154 * *$ & $-0.220 * * *$ & $-0.187 * * *$ & -0.0133 \\
\hline & $(0.0370)$ & $(0.0754)$ & $(0.0669)$ & $(0.0482)$ & $(0.0837)$ \\
\hline \multirow[t]{2}{*}{ ZScore } & $0.0152 * * *$ & $0.0221 *$ & 0.00223 & $0.0187 * *$ & 0.0133 \\
\hline & $(0.00545)$ & $(0.0120)$ & $(0.00657)$ & $(0.00788)$ & $(0.0100)$ \\
\hline \multirow[t]{2}{*}{ EAS } & 0.00888 & -0.0218 & & 0.0714 & -0.0544 \\
\hline & $(0.0431)$ & $(0.240)$ & & $(0.0636)$ & $(0.0806)$ \\
\hline \multirow[t]{2}{*}{ Dual } & 0.0486 & & -0.0110 & $0.242 * *$ & -0.0832 \\
\hline & $(0.0688)$ & & $(0.146)$ & (0.113) & $(0.117)$ \\
\hline \multirow[t]{2}{*}{ Fam } & $-1.020 * * *$ & & & $-0.579 *$ & $-1.178 * * *$ \\
\hline & $(0.226)$ & & & $(0.328)$ & $(0.384)$ \\
\hline \multirow[t]{2}{*}{ Bsize } & -0.0204 & 0.0458 & 0.0178 & -0.0143 & -0.0104 \\
\hline & $(0.0150)$ & $(0.0389)$ & $(0.0246)$ & $(0.0217)$ & $(0.0271)$ \\
\hline \multirow[t]{2}{*}{ Nexc } & 0.108 & -0.00773 & 0.0301 & 0.112 & 0.108 \\
\hline & $(0.250)$ & $(0.595)$ & $(0.324)$ & $(0.348)$ & $(0.452)$ \\
\hline \multirow[t]{2}{*}{ Constant } & $2.213 * * *$ & $2.153^{*}$ & $3.190 * * *$ & $2.860 * * *$ & 0.754 \\
\hline & $(0.582)$ & (1.285) & (1.026) & $(0.735)$ & (1.358) \\
\hline
\end{tabular}




$\begin{array}{lccccc}\text { Observations } & 338 & 115 & 178 & 175 & 163 \\ \text { R-squared } & 0.603 & 0.871 & 0.299 & 0.780 & 0.172\end{array}$

Standard errors in parentheses

$* * * \mathrm{p}<0.01, * * \mathrm{p}<0.05, * \mathrm{p}<0.1$

Table (6): The Results of Real Income-Smoothing Model.
(1)
(2)
(3)
(4)
(5)

VARIABLES

Total Sample

Before 2007

After 2007

Negative

Positive

\begin{tabular}{|c|c|c|c|c|c|}
\hline \multirow[t]{2}{*}{$\Delta$ Earnings } & $-0.105 * * *$ & $-0.0183 * * *$ & $-0.168 * * *$ & $-0.168 * * *$ & $0.173 * * *$ \\
\hline & $(0.0276)$ & $(0.00603)$ & $(0.0383)$ & $(0.0540)$ & $(0.0610)$ \\
\hline \multirow[t]{2}{*}{ Debt } & -0.000187 & 0.00004 & -0.00027 & -0.00725 & 0.00004 \\
\hline & $(0.00135)$ & $(0.00075)$ & $(0.00197)$ & $(0.0132)$ & $(0.0013)$ \\
\hline \multirow[t]{2}{*}{$\mathrm{CR}$} & -0.000449 & -0.00005 & -0.00028 & -0.00136 & -0.00023 \\
\hline & $(0.00064)$ & $(0.00038)$ & $(0.00089)$ & (0.00199) & $(0.00066)$ \\
\hline \multirow[t]{2}{*}{ Sales } & 0.000003 & 0.00001 & 0.00005 & 0.00005 & -0.00022 \\
\hline & $(0.00025)$ & $(0.00008)$ & $(0.00031)$ & $(0.00046)$ & $(0.00036)$ \\
\hline \multirow[t]{2}{*}{ Size } & 0.00114 & 0.00023 & 0.00134 & -0.00477 & 0.00340 \\
\hline & $(0.00222)$ & $(0.00042)$ & $(0.00572)$ & $(0.0051)$ & $(0.00246)$ \\
\hline \multirow[t]{2}{*}{ ZScore } & $0.000558^{*}$ & 0.00001 & 0.00037 & 0.00047 & 0.000227 \\
\hline & $(0.00033)$ & $(0.00007)$ & $(0.00056)$ & $(0.00085)$ & $(0.00037)$ \\
\hline \multirow[t]{2}{*}{ EAS } & -0.00044 & -0.000176 & & 0.00737 & -0.00108 \\
\hline & $(0.00260)$ & $(0.00134)$ & & $(0.00747)$ & $(0.00253)$ \\
\hline \multirow[t]{2}{*}{ Dual } & 0.00241 & & -0.00021 & 0.00311 & 0.00369 \\
\hline & $(0.00414)$ & & $(0.0125)$ & $(0.0132)$ & $(0.0037)$ \\
\hline \multirow[t]{2}{*}{ Fam } & -0.00241 & & & -0.0178 & -0.0060 \\
\hline & $(0.0136)$ & & & $(0.0319)$ & $(0.0143)$ \\
\hline
\end{tabular}




$\begin{array}{lccccc}\text { Bsize } & 0.00005 & -0.00002 & -0.00063 & -0.00129 & 0.00011 \\ & (0.00089) & (0.00022) & (0.0021) & (0.0024) & (0.0009) \\ \text { Nexc } & -0.0131 & -0.00022 & 0.00376 & 0.00083 & -0.0027 \\ & (0.0150) & (0.00332) & (0.0276) & (0.0328) & (0.0156) \\ \text { Constant } & -0.00788 & -0.00121 & -0.0172 & 0.0803 & -0.0473 \\ & (0.0350) & (0.00719) & (0.0876) & (0.0799) & (0.0383) \\ & & & & & 188 \\ \text { Observations } & 338 & 115 & 178 & 150 & 0.102 \\ \text { R-squared } & 0.065 & 0.125 & 0.143 & 0.152 & \\ \end{array}$

Standard errors in parentheses

*** $\mathrm{p}<0.01, * * \mathrm{p}<0.05, * \mathrm{p}<0.1$ 
Table (7): DA- Performance matched Discretionary Accruals Model

\begin{tabular}{l} 
KARIABLES $\quad \begin{array}{l}\text { Kothari et } \\
\text { al. (2005) }\end{array}$ \\
\hline
\end{tabular}

$\begin{array}{lr}\Delta \text { Earnings } & 1.608 * * * \\ & (0.240) \\ \text { Debt } & 0.0109 \\ & (0.459) \\ \text { CR } & 0.00977 \\ & (0.217) \\ \text { Sales } & -0.0152 \\ & (0.0837) \\ \text { Size } & 0.135 \\ & (0.752)\end{array}$

ZScore

0.0748

(0.111)

EAS

$-1.265$

(0.877)

Dual

0.0606

(1.400)

Fam

0.858

(4.596)

Bsize

0.356

(0.306)

Nexc

$-2.816$

(5.084)

Constant

$-2.966$

(11.84)

Observations 
Standard errors in parentheses

$* * * \mathrm{p}<0.01, * * \mathrm{p}<0.05, * \mathrm{p}<0.1$ 


\begin{tabular}{|c|c|c|c|}
\hline \multicolumn{4}{|c|}{ Table (8): Results of Model (4) } \\
\hline & (1) & (2) & (3) \\
\hline VARIABLES & Total sample & Negative & Positive \\
\hline \multirow[t]{2}{*}{ I/LAS } & -0.113 & 9.359 & 0.106 \\
\hline & $(0.997)$ & $(16.52)$ & $(1.293)$ \\
\hline \multirow[t]{2}{*}{$\Delta$ Earnings DA } & $0.232 * * *$ & $0.237 * * *$ & 0.197 \\
\hline & $(0.0125)$ & $(0.0138)$ & $(0.159)$ \\
\hline \multirow[t]{2}{*}{ Debt } & 0.00601 & 0.0116 & 0.0113 \\
\hline & $(0.0226)$ & $(0.0348)$ & $(0.0446)$ \\
\hline \multirow[t]{2}{*}{$\mathrm{CR}$} & 0.00280 & 0.00835 & 0.00706 \\
\hline & $(0.0107)$ & $(0.0198)$ & $(0.0174)$ \\
\hline \multirow[t]{2}{*}{ Sales } & 0.00208 & 0.00437 & -0.00489 \\
\hline & $(0.0041)$ & $(0.0055)$ & $(0.0108)$ \\
\hline \multirow[t]{2}{*}{ Size } & $-0.115 * * *$ & $-0.185^{* * *}$ & -0.0134 \\
\hline & $(0.0371)$ & $(0.0485)$ & $(0.0841)$ \\
\hline \multirow[t]{2}{*}{ ZScore } & $0.0152 * * *$ & $0.0183 * *$ & 0.0133 \\
\hline & $(0.00548)$ & $(0.00794)$ & $(0.0101)$ \\
\hline \multirow[t]{2}{*}{ EAS } & 0.00895 & 0.0645 & -0.0543 \\
\hline & $(0.0432)$ & $(0.0649)$ & $(0.0810)$ \\
\hline \multirow[t]{2}{*}{ Dual } & 0.0490 & $0.238 * *$ & -0.0834 \\
\hline & $(0.0690)$ & (0.114) & (0.118) \\
\hline \multirow[t]{2}{*}{ Fam } & $-1.021 * * *$ & $-0.567 *$ & $-1.177 * * *$ \\
\hline & $(0.226)$ & $(0.330)$ & $(0.386)$ \\
\hline \multirow[t]{2}{*}{ Bsize } & -0.0204 & -0.0142 & -0.0104 \\
\hline & $(0.0151)$ & $(0.0218)$ & $(0.0272)$ \\
\hline \multirow[t]{2}{*}{ Nexc } & 0.107 & 0.119 & 0.111 \\
\hline & $(0.251)$ & $(0.349)$ & $(0.456)$ \\
\hline Constant & $2.211 * * *$ & $2.822 * * *$ & 0.752 \\
\hline
\end{tabular}


$\begin{array}{lll}(0.583) & (0.740) \quad(1.365)\end{array}$

$\begin{array}{lccc}\text { Observations } & 338 & 175 & 163 \\ \text { R-squared } & 0.603 & 0.780 & 0.172\end{array}$

Standard errors in parentheses

$* * * \mathrm{p}<0.01, * * \mathrm{p}<0.05, * \mathrm{p}<0.1$

Table (9): Results of Model (5)

\begin{tabular}{lccc}
\hline & $(1)$ & $(2)$ & $(3)$ \\
VARIABLES & Total sample & Negative & Positive \\
\hline \multirow{2}{*}{ DA } & & & \\
& 0.00121 & 0.00275 & 0.00044 \\
\multirow{2}{*}{$\Delta$ Earnings-I/LAS } & $-0.105 * * *$ & $-0.167 * * *$ & $0.172 * * *$
\end{tabular}




\begin{tabular}{|c|c|c|c|}
\hline & $(0.0276)$ & $(0.0544)$ & $(0.0614)$ \\
\hline \multirow[t]{2}{*}{ Debt } & -0.00020 & -0.00738 & 0.00003 \\
\hline & $(0.00136)$ & $(0.0133)$ & $(0.0013)$ \\
\hline \multirow[t]{2}{*}{$\mathrm{CR}$} & -0.00045 & -0.00143 & -0.00023 \\
\hline & $(0.00064)$ & $(0.00204)$ & $(0.00067)$ \\
\hline \multirow[t]{2}{*}{ Sales } & -0.0000007 & 0.00003 & -0.00022 \\
\hline & $(0.00025)$ & $(0.00047)$ & $(0.0004)$ \\
\hline \multirow[t]{2}{*}{ Size } & 0.00124 & -0.00428 & 0.00339 \\
\hline & $(0.00223)$ & $(0.00573)$ & $(0.0025)$ \\
\hline \multirow[t]{2}{*}{ ZScore } & 0.000540 & 0.000473 & 0.00022 \\
\hline & $(0.00033)$ & $(0.00085)$ & $(0.0004)$ \\
\hline \multirow[t]{2}{*}{ EAS } & -0.000489 & 0.00693 & -0.00111 \\
\hline & $(0.00261)$ & $(0.0078)$ & $(0.00254)$ \\
\hline \multirow[t]{2}{*}{ Dual } & 0.00237 & 0.00254 & 0.00369 \\
\hline & $(0.00414)$ & $(0.0136)$ & $(0.0037)$ \\
\hline \multirow[t]{2}{*}{ Fam } & -0.00103 & -0.0165 & -0.00523 \\
\hline & $(0.0139)$ & $(0.0328)$ & $(0.0148)$ \\
\hline \multirow[t]{2}{*}{ Bsize } & 0.000136 & -0.00128 & 0.00018 \\
\hline & $(0.00091)$ & $(0.0024)$ & $(0.00097)$ \\
\hline \multirow[t]{2}{*}{ Nexc } & -0.0134 & 0.00095 & -0.00285 \\
\hline & $(0.0151)$ & $(0.0330)$ & $(0.0157)$ \\
\hline \multirow[t]{2}{*}{ Constant } & -0.0105 & 0.0728 & -0.0479 \\
\hline & $(0.0354)$ & $(0.0888)$ & $(0.0386)$ \\
\hline Observations & 338 & 150 & 188 \\
\hline R-squared & 0.066 & 0.153 & 0.102 \\
\hline
\end{tabular}

Standard errors in parentheses

$* * * \mathrm{p}<0.01, * * \mathrm{p}<0.05, * \mathrm{p}<0.1$ 